\title{
Spontaneous umbilical cord haematoma
}

\author{
Fábia Mota, ${ }^{1,2}$ Nuno Oliveira, ${ }^{1,3}$ Margarida Fonseca, ${ }^{1}$ Gabriela Mimoso ${ }^{1}$
}

${ }^{1}$ Neonatal Intensive Care Unit, Maternidade Bissaya Barreto, Centro Hospitalar e Universitário de Coimbra, Coimbra, Portugal ${ }^{2}$ Pediatric Unit, Centro Hospitalar Tondela-Viseu EPE, Viseu, Portugal

${ }^{3}$ Pediatric Unit, Centro Hospitalar do Baixo Vouga EPE, Aveiro, Portugal

\section{Correspondence to}

Dr Fábia Mota,

fabia.pmota@gmail.com

Accepted 24 May 2019

\section{DESCRIPTION}

Spontaneous umbilical cord haematoma (SUCH) is a rare complication of delivery, associated with high mortality and causing fetal distress and stillbirth. Perinatal loss rate is about 50\% and its incidence in live births is approximately one in 11000 pregnancies. ${ }^{1}$ It occurs from the rupture of the umbilical veins and the cause of bleeding is uncertain. Risk factors for SUCH include morphologic anomalies of the umbilical cord (length or thickness), true knots, cord prolapse, traction or shortness of the cord, infection or postmaturity. ${ }^{2}$

We describe a newborn girl, born at 39 weeks gestational age with a small swelling of the umbilical cord stump. She was born by vaginal delivery, following an uneventful pregnancy with normal scans and serology. There was no history of any invasive fetal procedures, fetal distress or trauma during pregnancy and delivery. Six hours after delivery, a marked increase of the umbilical cord stump was noticed, with a $4 \times 3 \mathrm{~cm}^{2}$ reddish, nontender swelling (figure 1). Physical examination was otherwise unremarkable. She was admitted to the neonatal unit for observation and a normal haemostasis study and negative septic scan. No major morphological placenta changes had been observed and no anatomopathologic study was done. Umbilical cord stump swelling evolved to mummification, without specific treatment. The newborn was discharged on the fourth day, and was observed after 1 and 2 weeks. The umbilical cord

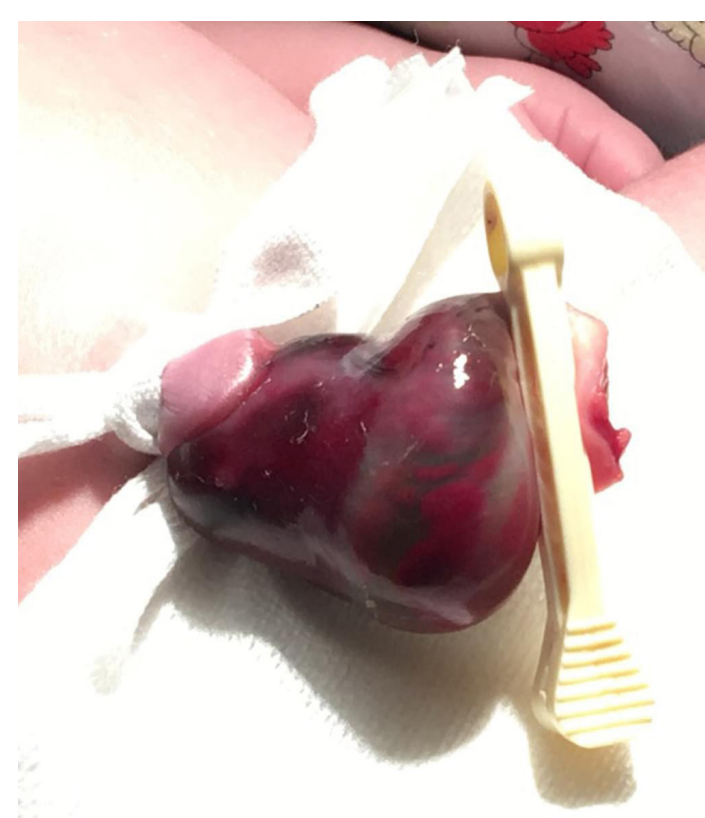

Figure 1 Increase of the umbilical cord with a reddish, nontender swelling suggesting an umbilical cord haematoma.

\section{Learning points}

- Umbilical cord haematoma is a rare condition.

- Most common causes include umbilical cord trauma, coagulation disorders and infection, but it can also occur spontaneously.

- In spite of being potentially fatal, if detected in an asymptomatic newborn it is associated with a good prognosis.

stump had not fallen, leading to a small procedure to remove it, uneventfully.

Despite the risk factors described, SUCH can occur secondary to in utero instrumentations such as amniocentesis or fetal diagnostic procedures, after abdominal trauma in pregnancy, due to coagulation disorders or infectious conditions, but it can also occur spontaneously. ${ }^{3}$ When detected in utero, it implies greater vigilance, as fetal hypoxia and anaemia may occur, leading to perinatal asphyxia and stillbirth. In those cases, fetal heart monitor tracing is advised as abnormal changes may occur. ${ }^{45}$ However, as we saw in our case, when incidentally detected in the newborn, it usually has a benign course.

Contributors FM participated on the provided care, took the photos, wrote the manuscript, contributed to paper's bibliographical research. NO participated on the provided care given to the article's described newborn, as well as on the paper's bibliographical research. MF contributed on the newborn's initial approach, either on the provided care, bibliographical research and on the elaboration of the submitted paper. GM contributed on the newborn's given care, bibliographical research and on the to be submitted paper's review. All authors contributed to the final manuscript.

Funding The authors have not declared a specific grant for this research from any funding agency in the public, commercial or not-for-profit sectors.

Competing interests None declared.

Patient consent for publication Parental/guardian consent obtained.

Provenance and peer review Not commissioned; externally peer reviewed.

\section{REFERENCES}

1 Scutiero G, Bernardi G, lannone P, et al. Corrigendum to "Umbilical Cord Hematoma: a Case Report and Review of the Literature". Obstet Gynecol Int 2018;2018:1.

2. Sizun J, Soupre D, Broussine L, et al. [Spontaneous umbilical cord hematoma, a rare cause of acute fetal distress]. Archives de Pédiatrie 1995;2:1182-3

3 Gualandri G, Rivasi F, Santunione AL, et al. Spontaneous umbilical cord hematoma: an unusual cause of fetal mortality: a report of 3 cases and review of the literature. Am J Forensic Med Pathol 2008:29:185-90.

4 Seoud M, Aboul-Hosn L, Nassar A, et al. Spontaneous umbilical cord hematoma: a rare cause of acute fetal distress. Am J Perinatol 2001;18:099-102. 


\section{Images in...}

Copyright 2019 BMJ Publishing Group. All rights reserved. For permission to reuse any of this content visit https://www.bmj.com/company/products-services/rights-and-licensing/permissions/

BMJ Case Report Fellows may re-use this article for personal use and teaching without any further permission.

Become a Fellow of BMJ Case Reports today and you can:

- Submit as many cases as you like

- Enjoy fast sympathetic peer review and rapid publication of accepted articles

- Access all the published articles

- Re-use any of the published material for personal use and teaching without further permission

Customer Service

If you have any further queries about your subscription, please contact our customer services team on +44 (0) 2071111105 or via email at support@bmj.com.

Visit casereports.bmj.com for more articles like this and to become a Fellow 